\title{
Novel $\mathrm{I}_{1}$-imidazoline $\mathrm{S} 43126$ enhance insulin action in PC12 cells
}

\author{
Jerusalem Tesfai ${ }^{1}$, Louis Crane ${ }^{2}$, Genevieve Baziard-Mouysset ${ }^{2}$, \\ Wentsworth Kennedy ${ }^{3}$, Lincoln P. Edwards ${ }^{3}$ \\ ${ }^{1}$ Department of Biochemistry, Loma Linda University School of Medicine, Loma Linda, CA 92350, USA \\ ${ }^{2}$ Laboratoire de Chimie Pharmaceutique, Universite Paul Sabatier, Faculté de Pharmacie, F-31062 Toulouse \\ Cedex 9, France \\ ${ }^{3}$ Schools of Dentistry/Medicine, Loma Linda University, Loma Linda, CA 92350, USA
}

Correspondence: Lincoln P. Edwards, e-mail: Ipedwards@llu.edu

\begin{abstract}
:
The $\mathrm{I}_{1}$-imidazoline receptor is a novel target for drug development for hypertension and insulin resistance, major disorders associated with type 2 diabetes. In the present study, we examined the effects of a novel imidazoline agonist S43126, on phosphorylation of protein kinase B (PKB/Akt) and extracellular signal-regulated kinase (ERK1/2) in PC12 cells. We further examined the effects of S43126 on insulin stimulated PKB and ERK phosphorylation. PC12 cells were treated with varying doses of S43126 $\left(10^{-10}\right.$ to $\left.10^{-6} \mathrm{M}\right)$ or insulin $\left(10^{-10}\right.$ to $\left.10^{-6} \mathrm{M}\right)$ or combination treatment with insulin $\left(10^{-6} \mathrm{M}\right)$ and varying doses of S43126 $\left(10^{-6}-10^{-11} \mathrm{M}\right)$ for $10 \mathrm{~min}$. Western blot analysis of treated samples showed that S43126 increased both ERK1/2 and PKB phosphorylation by 5 fold. Combination treatment with insulin $\left(10^{-6} \mathrm{M}\right)$ and varying doses of S43126 $\left(10^{-6}-10^{-11} \mathrm{M}\right)$ enhanced phosphorylation of PKB and ERK1/2 above the level of insulin alone, in a dose and time dependent manner. Treatment with siRNA against Nischarin (mouse homologue of $\mathrm{I}_{1}$-imidazoline receptor) reduced the phosphorylation of both ERK and PKB following combination treatments. These results indicate that S43126 has the potential to augment insulin action and should be further studied as a possible candidate drug for the treatment of insulin resistance states.
\end{abstract}

Key words:

$\mathrm{I}_{1}$-imidazoline receptor, protein kinase $\mathrm{B}$, extracellular signal-regulated kinase, insulin, nischarin, type 2 diabetes, insulin resistance

\section{Introduction}

Pharmacologic treatment of type 2 diabetes utilizes sulfonylurea drugs which are linked to an increased risk of oral cancer [2], and metformin which is associated with lactic acidosis [19]. Novel agents with fewer risks are needed as treatment options. The
$I_{1}$-imidazoline receptor $\left(I_{1} R\right)$ found in the rostral ventrolateral medulla (RVLM) is a novel target for drug development for hypertension and insulin resistance, major disorders associated with Metabolic Syndrome $\mathrm{X}$ and type 2 diabetes. Basic and clinical research reveal that imidazoline compounds, such as moxonidine, act centrally to lower blood pressure [7,9] and are insulin sensitizing agents $[3,13]$. Moxonidine has 
been shown to ameliorate elements of metabolic syndrome in both animals and humans. Moxonidine treatment improved glucose disposal and increased insulin-stimulated phosphorylation of key insulin signaling intermediates $[6,8,10,26]$ in the spontaneously hypertensive rat (SHROB; Koletsky rat) model of metabolic syndrome. The beneficial effects of moxonidine on elements of the metabolic syndrome extend to humans with similar disorders. When insulin resistant obese patients with mild hypertension were treated with moxonidine and evaluated by hyperinsulinemic euglycemic clamp technique, there was an improvement in insulin sensitivity [12].

Unfortunately, clinically useful $\mathrm{I}_{1} \mathrm{R}$ agonists such as moxonidine and clonidine are also agonists at $\alpha$ adrenergic receptors. Novel compounds that activate the imidazoline signaling pathways without demonstrated effects at $\alpha$-adrenergic receptors are needed to advance the field of imidazoline research. In this study, we utilize a selective imidazoline compound (S43126) whose binding characteristics have been determined by our collaborators. S43126 has the following binding properties, $\mathrm{pKiI}_{1}=7.46, \mathrm{pKi \alpha}_{1}<5.00$, and $\mathrm{pKi}_{2}<5.00$ [1]. It is yet to be determined whether this compound has any functional effects at adrenergic receptors or whether it has the ability to activate the $\mathrm{I}_{1}$-imidazoline signaling pathways. It is the aim of this study to provide insights into these questions.

The predominant cellular model for investigation of $I_{1} R$ signaling has been PC12 rat pheochromocytoma cells. These cells express a high density of $\mathrm{I}_{1}$-imidazoline binding sites in their plasma membranes and lack $\alpha_{2}$-adrenergic receptors, which recognize many $\mathrm{I}_{1}$-imidazoline ligands $[6,21]$.

The imidazoline receptor protein termed imidazoline receptor antisera selective (IRAS) has been cloned from human hippocampus [16, 22, 23] and the finding that hIRAS associates with insulin receptor substrate 4 (IRS-4) in human embryonic kidney 293 cells (HEK293 cells) led to the concept of IRAS involvement in insulin signaling pathways [24]. Nischarin, is the truncated form (PX domain missing) of mouse IRAS, and nischarin antisense oligodeoxynucleotide was shown to abolish the expression of nischarin and eliminated the production of ERK1/2 in PC12 cells following treatment by rilmenidine, an $\mathrm{I}_{1} \mathrm{R}$ agonist [27].

In this present study, we investigated whether S43126, a selective imidazoline compound, modulates insulin action on ERK 1/2 and PKB phosphorylation in $\mathrm{PC} 12$ cells.

\section{Materials and Methods}

\section{Tissue preparation and dose response relationships}

All protocols were approved by the Loma Linda University Animal Care and Use Committee. Doseresponse relationships were carried out on tail arteries of male adult Sprague-Dawley rats $(200-300 \mathrm{~g})$ as previously described by us [11]. Briefly, rats were decapitated and the ventral tail arteries were dissected out, cleaned and then cut into individual ring segments. After removal of the endothelium, vessels were mounted and immersed in tissue baths containing Krebs physiological solution (KPS) at $37^{\circ} \mathrm{C}$ equilibrated with $95 \% \mathrm{O}_{2}-5 \% \mathrm{CO}_{2}$ for $1 \mathrm{~h}$, and then stretched slowly to a preload of $1 \mathrm{~g}$. Dose-response curves of developed tension were then obtained using clonidine $\left(10^{-10}\right.$ to $\left.10^{-4} \mathrm{M}\right)$, an $\mathrm{I}_{1} / \alpha_{2}$-adrenergic agonist, and $\mathrm{S} 43126\left(10^{-10}\right.$ to $\left.10^{-4} \mathrm{M}\right)$, an $\mathrm{I}_{1}$-receptor agonist. Developed tension data were normalized relative to the maximum response to $106 \mathrm{mM}$ potassium.

\section{Antibodies and reagents}

Primary antibodies used were p44/42 MAP kinase, phospho-p44/42 MAP kinase (Thr-202/Tyr-204), Akt, phospho-Akt (Ser473) antibody diluted 1:1000, which were detected using a secondary antibody (HRP linked anti-rabbit $\operatorname{IgG}$ ) diluted 1:2000 and enhanced chemiluminescence (ECL, Amersham Pharmacia Biotech).

\section{Cell culture and drug treatment}

PC12 cells were cultured in RPMI 1640 medium (Cellgro, USA) supplemented with 10\% FBS, $5 \mathrm{ml}$ penicillin/streptomycin/amphotericin B solution (Sigma, USA) and maintained in the presence of $5 \% \mathrm{CO}_{2}$ at $37^{\circ} \mathrm{C}$. PC12 cells were treated with either $\mathrm{S} 43126$ or insulin at different concentrations $\left(10^{-11}-10^{-6} \mathrm{M}\right)$ and for various times $(0-180 \mathrm{~min})$. Treated cells were lysed and aliquots were subjected to western blotting using appropriate antibodies.

\section{Nischarin siRNA}

Expression of endogenous nischarin was specifically silenced in PC12 cells using mouse 20-25 nucleotide 
siRNA duplexes (Santa Cruz Biotechnology). Transfection was performed according to the manufacturer's instructions.

\section{Statistical analysis}

Data were analyzed using one-way analysis of variance (ANOVA) or Tukey's test for pair-wise multiple comparison to identify significant differences $(\mathrm{p}>$ 0.05 ) between individual groups.

\section{Results}

\section{Comparison of clonidine and \$43126}

Concentration-response curves for clonidine and novel imidazoline compound S43126 were determined in order to test whether S43126 caused contraction of tail artery similar to the known imidazoline agonist, clonidine. Clonidine $\left(\mathrm{EC}_{50}=0.5 \mu \mathrm{M}, \mathrm{E}_{\max }=56 \%\right)$ increased tension development in rat-tail artery (Fig. 1) in a dose-dependent manner, however, the novel imidazoline compound S43126 produced no significant contraction of tail artery at doses up to $100 \mu \mathrm{M}$.

\section{Effects of S43126 on ERK1/2 and PKB phosphorylation}

We tested the ability of S43126 to activate ERK1/2 and PKB which are components of both insulin and imidazoline signaling pathways. S43126 $\left(10^{-10}-10^{-5} \mathrm{M}\right)$ at all concentrations caused increased phosphorylation of ERK1/2 above DMSO (0.05\%) control (Fig. 2A). Peak phosphorylation occurred at $1 \mathrm{nM}$ concentration of S43126 with higher concentrations producing less phosphorylation of ERK1/2. Nerve growth factor (NGF, $50 \mathrm{ng} / \mathrm{ml})$ was a positive control. S43126 $\left(10^{-11}-10^{-6} \mathrm{M}\right)$ caused a concentration-dependent increase in PKB phosphorylation $\left(10^{-11}-10^{-9} \mathrm{M}\right)$, followed by a plateau $\left(10^{-9}-10^{-7} \mathrm{M}\right)$, and then a decrease $\left(10^{-6} \mathrm{M}\right)$. There was a maximum five-fold increase in PKB phosphorylation above control seen at plateau doses of S43126 (Fig. 2B).

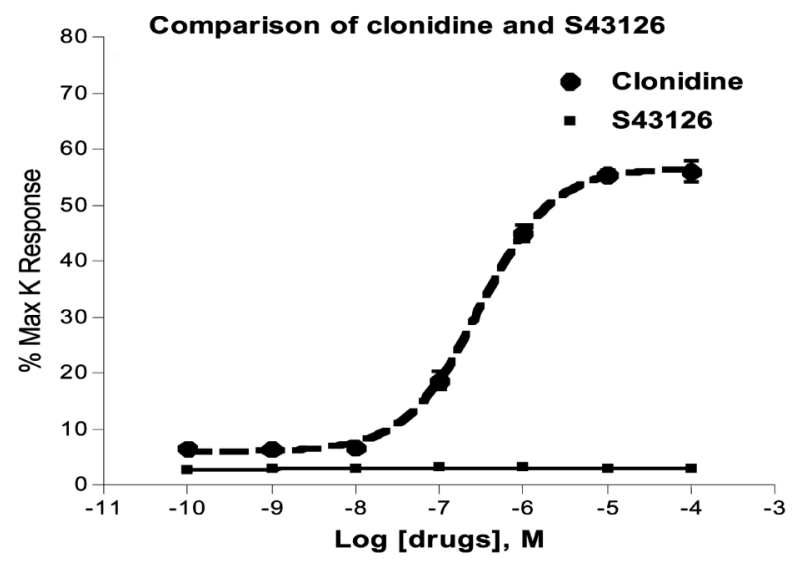

Fig. 1. Concentration-response relationship comparing induced-

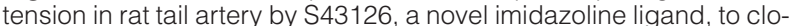
nidine. All contractile responses were expressed as percent of maxi$\mathrm{mal}$ responses to $106 \mathrm{mM}$ potassium. Data points are the mean \pm SEM for six experiments $(n=6)$

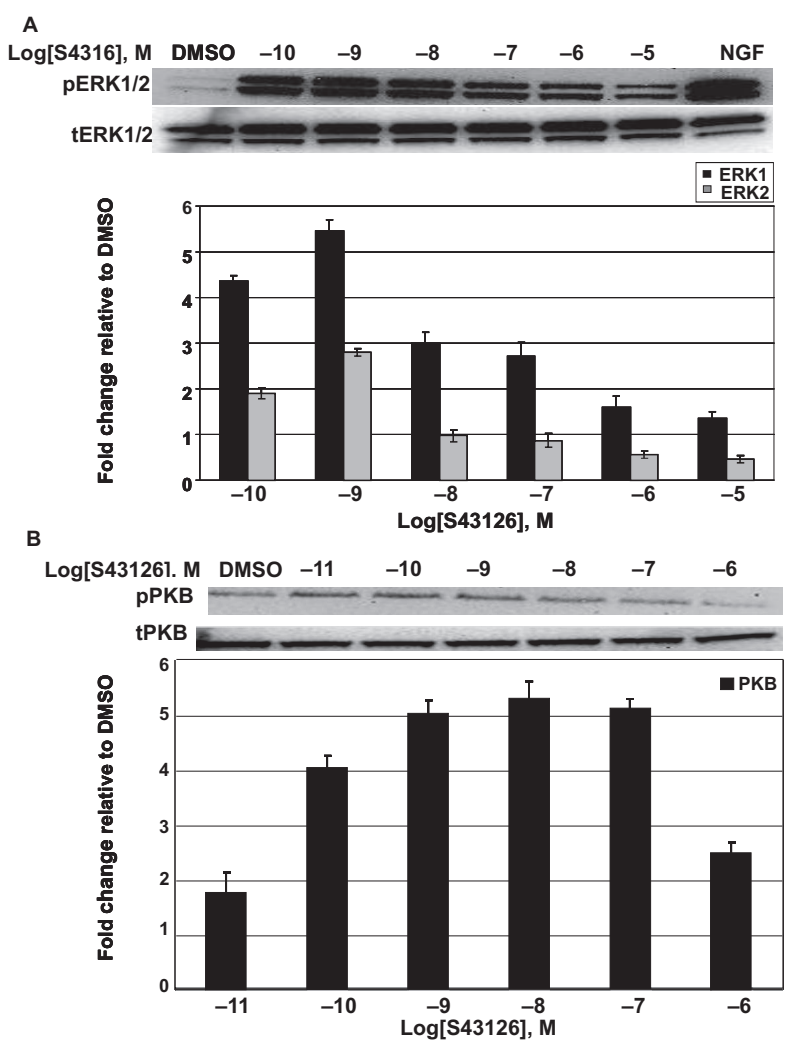

Fig. 2. Dose dependence of the activation of (A) ERK-1 and ERK-2 and (B) PKB by S43126. PC12 cells were treated with either NGF $(50 \mathrm{ng} / \mathrm{ml})$, vehicle $(0.05 \% \mathrm{DMSO})$ or S43126 $\left(10^{-6}-10^{-10} \mathrm{M}\right)$ for $10 \mathrm{~min}$. The relative phosphorylation of ERK-1/2 or PKB was defined by the ratio of the phosphorylated active form to total immunoreactive protein, in arbitrary absorbance units. The data were expressed relative to vehicle-treated controls run in parallel. Data are presented as the mean percent change \pm standard error from three separate experiments run in duplicate. Significant increase in ERK-1 and ERK-2 phosphorylation was detected at all doses of S43126 ( $p>0.001$ ANOVA). Significant increase in PKB phosphorylation was detected at $10^{-10}-10^{-7} \mathrm{M}(\mathrm{p}>0.001$, ANOVA $)$ 


\section{Effects of insulin combined with S43126 on phosphorylation of ERK1/2 and PKB}

Combination treatment with a fixed dose of insulin $\left(10^{-6} \mathrm{M}\right)$ and varying doses of S43126 $\left(10^{-10}-10^{-6} \mathrm{M}\right)$ for $10 \mathrm{~min}$, resulted in a greater phosphorylation of ERK1/ERK2 than was seen with insulin alone or S43126 alone. The combination of insulin $\left(10^{-6} \mathrm{M}\right)$ and $\mathrm{S} 43126\left(10^{-6} \mathrm{M}\right)$ produced a greater than 7 - and 6-fold phosphorylation of ERK-1 and ERK-2, respectively, above control (Fig. 3A). A time-course of ERK-1 and ERK-2 phosphorylation in response to combination treatment with insulin $\left(10^{-6} \mathrm{M}\right)$ and S43126 $\left(10^{-6} \mathrm{M}\right)$ produced a 7 - and 5-fold respective increase in phosphorylation above control, at both 5 and $10 \mathrm{~min}$. Longer times resulted in less phosphorylation of ERK1/2 (Fig. 3B). Combination treatment with a fixed dose of insulin $\left(10^{-6} \mathrm{M}\right)$ and varying doses of $\mathrm{S} 43126\left(10^{-10}-10^{-6} \mathrm{M}\right)$ for $10 \mathrm{~min}$, resulted in a greater phosphorylation of PKB than was seen with insulin $\left(10^{-6} \mathrm{M}\right)$ alone or S43126 $\left(10^{-6} \mathrm{M}\right)$ alone. The combination of insulin $\left(10^{-6} \mathrm{M}\right)$ and $\mathrm{S} 43126$ $\left(10^{-6} \mathrm{M}\right)$ produced an additive 10-fold increase in PKB phosphorylation compared to a 7-fold increase seen by treatment with insulin $\left(10^{-6} \mathrm{M}\right)$ alone or with the 2-fold increase seen with S43126 (Fig. 3C). A timecourse of PKB phosphorylation in response to combination treatment with insulin $\left(10^{-6} \mathrm{M}\right)$ and $\mathrm{S} 43126$ $\left(10^{-6} \mathrm{M}\right)$ produced a maximum 5-fold increase in PKB phosphorylation above control, at $10 \mathrm{~min}$ (Fig. 3D).
Fig. 3. Dose dependence of the activation of (A) ERK1/2, (C) PKB; and time dependence of the activation of (B) ERK and (D) PKB; following treatment of PC12 cells with combination of S43126 and insulin. PC12 cells were treated with both $\mathrm{S} 43126\left(10^{-6} \mathrm{M}\right)$ and insulin $\left(10^{-6} \mathrm{M}\right)$ for various times and analyzed for ERK-1/2 and PKB phosphorylation. Other cells were treated with either S43126 $\left(10^{-6}-10^{-10} \mathrm{M}\right)$, insulin $\left(10^{-6} \mathrm{M}\right)$ and their combination with constant insulin dose $\left(10^{-6} \mathrm{M}\right)$ and varying dose of S43126 $\left(10^{-6}-10^{-10} \mathrm{M}\right)$ for $10 \mathrm{~min}$. The relative phosphorylation of ERK-1/2 or PKB was defined by the ratio of the phosphorylated active form to total immunoreactive protein, in arbitrary absorbance units. The data were expressed relative to vehicletreated controls run in parallel. Data are presented as the mean percent change \pm standard error from three separate experiments run in duplicate. Insulin $\left(10^{-6} \mathrm{M}\right)$ combined with S43126 $\left(10^{-6} \mathrm{M}\right)$ enhanced phosphorylation of ERK-1 and ERK-2 above S43126 or insulin alone $(p>0.001$, ANOVA)
A
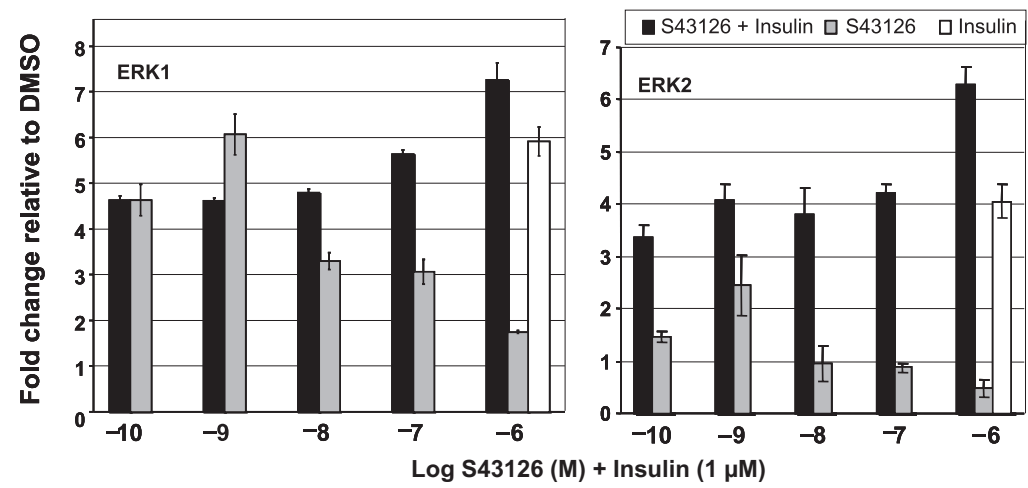

B
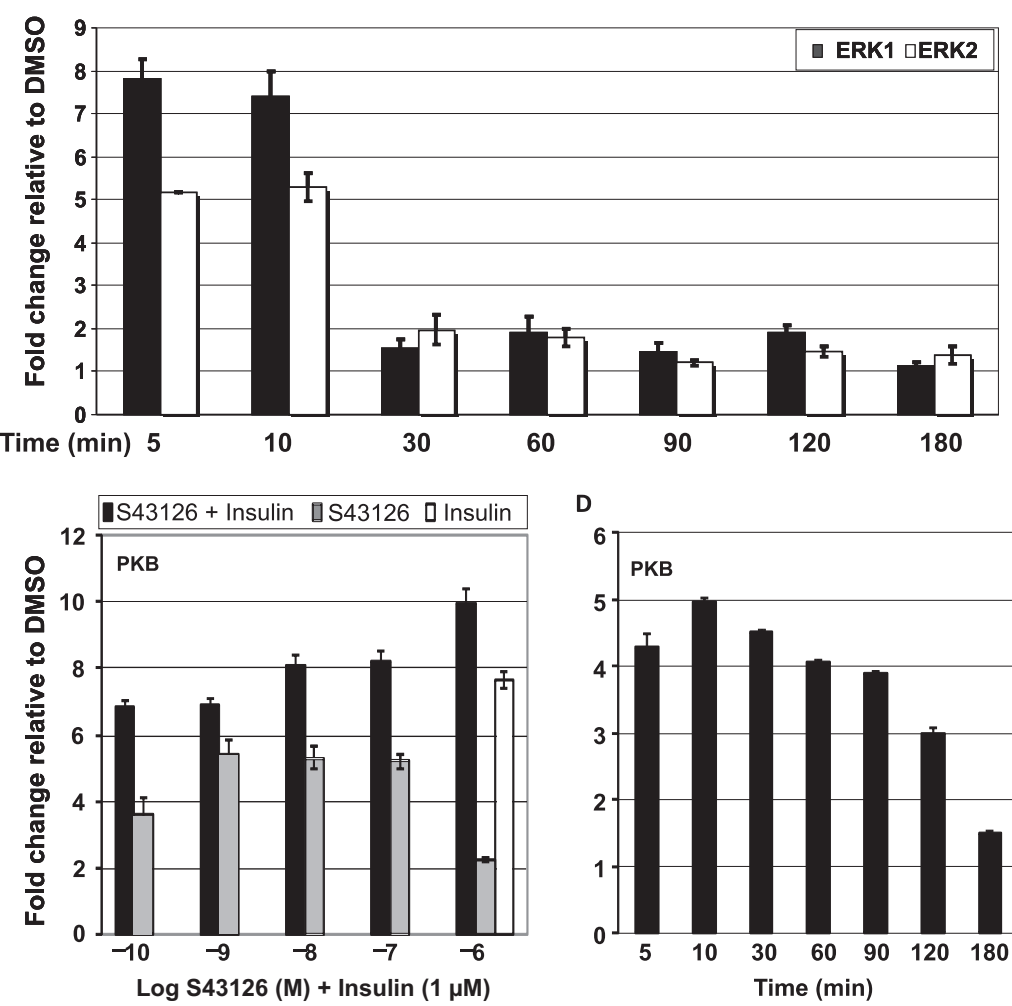

D

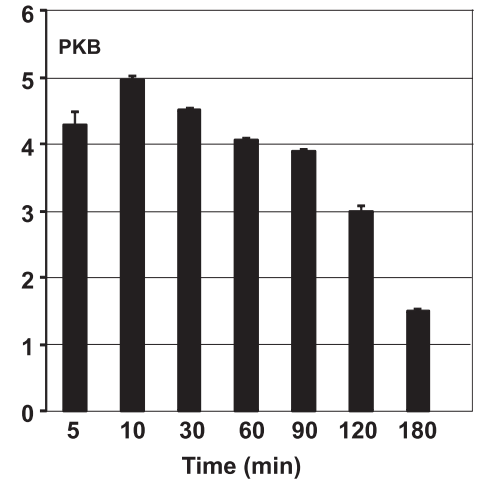




\section{Effects of NISCH siRNA on nischarin protein expression, ERK and PKB phosphorylation in combination treatments}

In order to test whether the effects of S43126 on ERK1/2 and PKB phosphorylation was mediated by $\mathrm{I}_{1}$-imidazoline receptor, we treated cells with nischarin siRNA, (mouse homologue of $\mathrm{I}_{1}$-imidazoline receptor). There was a greater than $50 \%$ reduction in the expression of nischarin protein in PC12 cells treated with siRNA, compared to cells treated with the combination of insulin $\left(10^{-6} \mathrm{M}\right)$ and $\mathrm{S} 43126\left(10^{-6} \mathrm{M}\right)$ for 10 min (Fig. 4A). PC12 cells treated with siRNA to nischarin showed a $50 \%$ reduction in the phosphorylation of both ERK-1 and ERK-2 following $10 \mathrm{~min}$ treatment with combination of insulin $\left(10^{-6} \mathrm{M}\right)$ and S43126 $\left(10^{-6} \mathrm{M}\right)$, compared to cells treated with the combination of insulin $\left(10^{-6} \mathrm{M}\right)$ and S43126 $\left(10^{-6} \mathrm{M}\right)$ for $10 \mathrm{~min}$ without siRNA to nischarin (Fig. 4B). Similarly, in PC12 cells treated with siRNA to nischarin, there was a greater than $35 \%$ decrease in $\mathrm{PKB}$ phosphorylation, compared to treated cells without nischarin siRNA (Fig. 4C).

\section{Discussion}

\section{Comparison of clonidine and S43126}

Tissue bath studies compared the contractile response of rat tail arterial strips to imidazoline compounds, clonidine and S43126 (Fig. 1). Clonidine binds to both $\mathrm{I}_{1} \mathrm{R}$ and $\alpha_{2}-\mathrm{AR}$ and contracted tail artery, whereas S43126 did not contract tail artery at concentrations up to $10^{-4} \mathrm{M}$ S43126. As previously shown, clonidine and moxonidine, common $\mathrm{I}_{1} \mathrm{R}$ agonists in clinical use, both contract rat tail artery by a mechanism involving both $\alpha_{2}$-AR and $\alpha_{1}$-AR activation $[11,17]$. The promiscuous nature of these imidazoline compounds have hampered development of this field of research and more selective ligands such as S43126 are needed to advance this important area of research. S43126 does not contract tail artery, suggesting that this compound is not an agonist at $\alpha$-AR. Binding studies previously published showed that S43126 had low affinity for $\alpha$-AR with $\mathrm{pKi} \alpha_{1}<5$ and $\mathrm{pKi} \alpha_{2}<5$ [1].

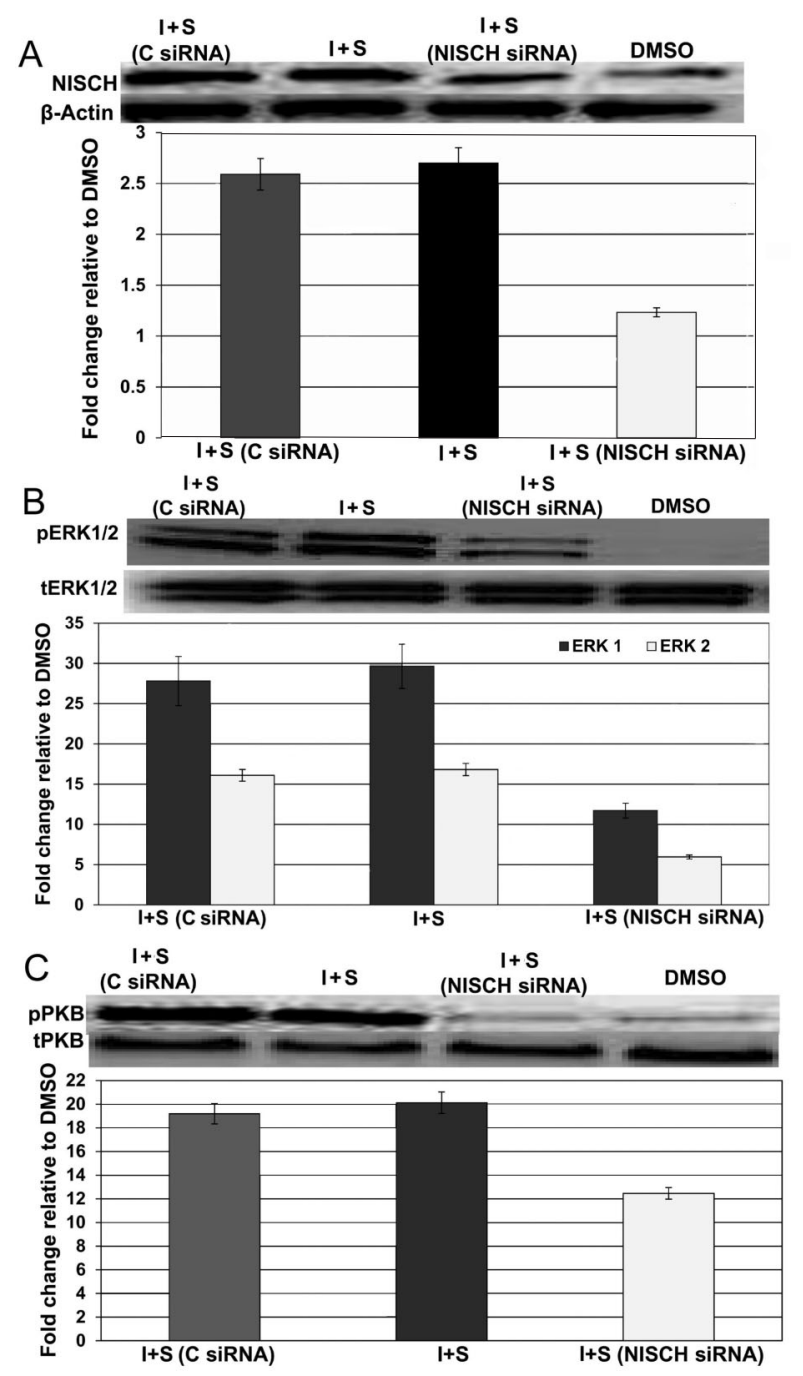

Fig. 4. Effects of siRNA NISCH (nischarin) treatment on (A) nischarin levels (B) ERK $1 / 2$ phosphorylation (C) PKB(Akt) phosphorylation. PC12 cells were treated with either combination of S43126 $\left(10^{-6} \mathrm{M}\right)$ and insulin $\left(10^{-6} \mathrm{M}\right)$ or combination of S43126 $\left(10^{-6} \mathrm{M}\right)$ and insulin $\left(10^{-6} \mathrm{M}\right)$ plus nischarin siRNA. The phosphorylation of PKB and ERK $1 / 2$ was determined as the ratio of the phosphorylated active form to total immunoreactive protein. Data are presented as the mean percent change \pm standard error from three separate experiments run in duplicate. PC12 cells treated with both S43126 and insulin $\left(10^{-6} \mathrm{M}\right)$ showed significantly higher levels of phosphorylated ERK-1/2 and PKB $(p>0.001)$ compared to cells treated with nischarin siRNA

\section{Effects of S43126 on ERK1/2 and PKB phosphorylation}

The present study showed that the novel imidazoline compound S43126 caused phosphorylation of proteins common to imidazoline and insulin signaling pathways. We first determined whether S43126 activated $\mathrm{I}_{1}$-imidazoline signaling pathways, in a manner similar to the known agonist, moxonidine. Our results 
showed that S43126 caused an increased phosphorylation of both ERK1/2 and PKB in a concentrationdependent manner (Fig. 3). ERK is a member of the family of mitogen-activated protein kinases (MAPK) and is phosphorylated in response to moxonidine binding to $\mathrm{I}_{1} \mathrm{R}$ in $\mathrm{PC} 12$ as shown previously [6]. Our present results showed that like moxonidine, S43126 also cause increased phosphorylation of ERK and PKB. Ernsberger's lab showed that in adipocytes isolated from SHROB treated with moxonidine in vivo, there was an improved response to insulin, both in terms of PKB activation and facilitation of glucose uptake [26]. Since receptors are defined by their signaling pathways, our data suggest that S43126 is an agonist at the imidazoline binding site. To our knowledge, S43126 is the first imidazoline compound that activated $\mathrm{I}_{1}$-signaling pathways, without apparent functional effects at adrenergic receptors.

\section{Effects of insulin combined with $\mathbf{S} 43126$ on phosphorylation of ERK1/2 and PKB}

Preliminary studies to determine the effect of various combinations of insulin and S43126 on ERK and PKB phosphorylation showed that optimum results were obtained with combination of insulin $\left(10^{-6} \mathrm{M}\right)$ and S43126 $\left(10^{-6} \mathrm{M}\right)$. This was surprising since based on the concentration-response curves, the maximum ERK phosphorylation in response to insulin was seen at $\left(10^{-6} \mathrm{M}\right)$ insulin and the maximum ERK response to $\mathrm{S} 43126$ was seen at $10^{-9} \mathrm{M}$. Concentrations of agonists that increase ERK phosphorylation tend to also activate mitogen activated protein kinase phosphatases (MKP) [5]. We have previously shown that while treatment of PC12 cells with NGF or moxonidine caused an increased phosphorylation of ERK, combination treatment with NGF and moxonidine resulted not in an expected increase in ERK phosphorylation, but rather a decrease. A decrease in ERK phosphorylation caused by the combination treatment of NGF and moxonidine was paralleled by an increase in MKP-2 induction [5]. Similarly, stimulation of angiotensin AT2 receptors in PC12 cells by angiotensin II, resulted in an enhanced phosphorylation of ERK within $10 \mathrm{~min}$, compared to untreated cells. Paradoxically, co-stimulation with NGF and angiotensin II resulted not in the expected additive effect on ERK phosphorylation but rather in a decrease, compared to NGF stimulation alone. The deactivation of ERK was paralleled by a rise in MKP-1 activity [15]. Possibly, treating PC12 cells with insulin and S43126 may activate MKP differentially, and the complex interplay between kinases and phosphatases produced an optimum measurable phosphorylation at micromolar concentrations of both insulin and S43126. Separate treatment with insulin or S43126 caused an increased phosphorylation of both ERK and PKB, while combination treatment with insulin and S43126 resulted in an additive increase in both ERK and PKB phosphorylation, compared to treatment by insulin alone. These data are consistent with an interaction between insulin and imidazoline receptor signaling pathways at the level of PKB and ERK, but do not conclusively establish such an interaction. Stimulation of PC12 cells by NGF leads to growth arrest and neuronal differentiation, whereas insulin induced metabolism of glucose and lipids [4]. However, it has been shown that $\mathrm{PC} 12$ cells overexpressing the insulin receptor undergoes insulin-dependent neuronal differentiation similar to that induced by NGF. Addition of insulin or clonidine to PC12 cells is known to induce cell proliferation [10, 23]. The kinetics of ERK activation in PC12 cells vary depending on the stimulating agent. NGF induced sustained stimulation and nuclear translocation of ERK, while insulin and imidazoline agonists induce transient stimulation of ERK [4, 6]. However, PC12 cells with overexpressed insulin receptors, when activated by insulin, resulted in prolonged ERK activation and nuclear translocation of the enzyme, similar to NGF [4]. This study found that the combination of insulin and S43126 caused a transient phosphorylation of ERK, with peak phosphorylation occurring at $10 \mathrm{~min}$. The increase in PKB phosphorylation seen with the combination of S43126 and insulin suggests that S43126 may have insulin sensitizing effects. The clinically useful imidazoline, moxonidine has been shown to improve insulin sensitivity by decreasing plasma insulin levels in patients with metabolic syndrome. Patients who had a high sympathetic drive at baseline, showed the greatest improvement [9]. Hence, although both insulin and $\mathrm{I}_{1}$-imidazoline agonist S43126 activated ERK1/2 and PKB in PC12 cells, combined treatments with both agents produced a greater net activation. Since S43126 is a novel compound, there may be additional pathways activated by this ligand that may impact our results. We note that even for $10^{-6} \mathrm{M} \mathrm{S} 43126$, we did not observe any contraction of tail artery strips. This suggests adrenergic activation may not play a dominant role in our results. 


\section{Effects of NISCH siRNA on nischarin protein expression, ERK and PKB phosphorylation in combination treatments}

To test whether the effect of S43126 $\left(10^{-6} \mathrm{M}\right)$ on ERK1/2 and PKB phosphorylation was mediated by $\mathrm{I}_{1}$-imidazoline receptor, we treated $\mathrm{PC} 12$ cells with siRNA to nischarin. There was a reduced expression of nischarin protein in $\mathrm{PC} 12$ cells treated with siRNA compared to untreated cells. PC12 cells treated with nischarin siRNA also showed decreased levels of phosphorylation of both ERK-1/2 and PKB, following combination treatment with insulin $\left(10^{-6} \mathrm{M}\right)$ and S43126 $\left(10^{-6} \mathrm{M}\right)$. The parallelism between decreased nischarin protein levels and decreased phosphorylation of both ERK1/2 and PKB, following combination treatment with insulin and S43126, suggests that there is cross-talk between $I_{1}$-imidazoline receptors and insulin receptors at the level of ERK and PKB. Similar to our findings, nischarin antisense oligodeoxynucleotide $(\mathrm{ODN})$ abolished the expression of nischarin in PC12 cells. Moreover, nischarin ODN eliminated the phosphorylation of ERK1/2 elicited by another $\mathrm{I}_{1}$-imidazoline agonist, rilmenidine, in PC12 cells [27]. Additional experiments were done using lower concentrations of S43126 $\left(10^{-9} \mathrm{M}\right)$ in combination with varying doses of insulin $\left(10^{-9}-10^{-5} \mathrm{M}\right)$ and also using insulin $\left(10^{-9} \mathrm{M}\right)$ with varying doses of S43126 $\left(10^{-9}\right.$ $\left.10^{-5} \mathrm{M}\right)$. These experiments did not show any significant changes in ERK or PKB phosphorylation (data not shown). There is an ongoing debate regarding the molecular identity of the $I_{1} R$. Previous studies of IRAS-transfected $\mathrm{CHO}$ and $\mathrm{PC} 12$ cells have shown an elevation in radioligand binding to $\mathrm{I}_{1} \mathrm{R}$ sites, as well as an enhanced activation of PC-PLC and ERK phosphorylation by imidazoline agonists. These changes could be blocked by efaroxan, a selective $\mathrm{I}_{1} \mathrm{R}$ antagonist $[5,6,18,25]$. Similarly, PC12 cells transfected with cDNA encoding nischarin, increased $\mathrm{I}_{1} \mathrm{R}$ binding sites as shown by radioligand binding studies. Nischarin antisense abolished both expression of protein as well as substantially reduced the generation of ERK elicited by $I_{1} R$ agonist [27]. Molderings and colleagues conducted radioligand binding experiments with clonidine and moxonidine in PC12 cells and concluded that $\mathrm{I}_{1} \mathrm{R}$ represented a mixture of S1P1/S1P3receptor hetero-dimers [20]. The investigators only used siRNA against S1P1/S1P3-receptors and concluded that the observed decreased binding of clonidine and moxonidine was sufficient to place $I_{1} R$ among the S1P-receptor family. The authors theorized that nischarin's role was to traffic $\mathrm{SIP} 1 / 3$ receptors from the cytosol to the membrane, hence overexpression of nischarin would increase SIP1/3 trafficking, resulting, in increased $\mathrm{I}_{1}$-imidazoline binding sites, as shown by Piletz [22]. While these explanations are plausible, the authors have yet to show that the signaling pathways coupled to $I_{1} R$ was affected by siRNA against S1P1/S1P3-receptors. Nonetheless, our results are not contradictory to their findings, since by their logic, knockdown of nischarin protein would reduce membrane bound SIP $1 / 3$ receptors and therefore decrease phosphorylation of the signaling molecules ERK and PKB. Our findings strengthen their argument since we showed that PKB is coupled to $I_{1} R$ and all SIP receptor agonists are known to activate PKB [14], a fact not mentioned by Molderings and colleagues.

In conclusion, S43126 is a novel compound with binding affinity for the $\mathrm{I}_{1} \mathrm{R}$ but with no functional effects at $\alpha$-AR, as evidenced by its inability to contract rat tail arterial strips. We have also shown that S43126 activated the $\mathrm{I}_{1}$-imidazoline signaling pathway by causing phosphorylation of both ERK and PKB. S43126 should be considered as an important ligand for imidazoline studies since it negates the need for $\alpha$ blockers. Since S43126 showed an additive effect with insulin on PKB phosphorylation, it has the potential to act as an insulin sensitizing agent, similar to moxonidine which is in clinical use.

\section{Acknowledgments:}

These studies were supported in part by NIH1R15DK084468-01A1 and the Center for Health Disparities at Loma Linda University.

\section{References:}

1. Anastassiadou M, Danoun S, Crane L, Baziard-Mouysset G, Payard M, Caignard D, Rettori M, Renard P: Synthesis and pharmacological evaluation of imidazoline sites $\mathrm{I}_{1}$ and $\mathrm{I}_{2}$ selective ligands. Bioorg Med Chem, 2001, 9, 585-592.

2. Bowker SL, Majumdar SR, Veugelers P, Johnson JA: Increased cancer-related mortality for patients with type 2 diabetes who use sulfonylureas or insulin. Diabetes Care, 2006, 29, 254-258.

3. De Luca N, Izzo R, Fontana D, Iovino G, Argenziano L, Vecchione C, Trimarco B: Haemodynamic and metabolic effects of rilmenidine in hypertensive patients with metabolic syndrome X. A double-blind parallel study versus amlodipine. J Hypertens, 2000, 18, 1515-1522. 
4. Dikic I, Schlessinger J, Lax I: PC12 Cells overexpressing the insulin receptor undergo insulin-dependent neuronal differentiation. Curr Biol, 1994, 4, 702-708.

5. Edwards L, Ernsberger P: The $\mathrm{I}_{1}$-imidazoline receptor in PC12 pheochromocytoma cells reverses NGF-induced ERK activation and induces MKP-2 phosphatase. Brain Res, 2003, 980, 71-79.

6. Edwards L, Fishman D, Horowitz P, Bourbon N, Kester $\mathrm{M}$, Ernsberger P: The $\mathrm{I}_{1}$-imidazoline receptor in PC12 pheochromocytoma cells activates protein kinases $\mathrm{C}$, extracellular signal-regulated kinase (ERK) and c-jun N-terminal kinase (JNK). J Neurochem, 2001, 79, 931-940.

7. Ernsberger P, Giuliano R, Willette RN, Reis DJ: Role of imidazoline receptors in the vasodepressor response to clonidine analogs in the rostral ventrolateral medulla. J Pharmacol Exp Ther, 1990, 253, 408-418.

8. Ernsberger P, Ishizuka T, Liu S, Farrell CJ, Bedol D, Koletsky RJ, Friedman JE: Mechanisms of antihyperglycemic effects of moxonidine in the obese spontaneously hypertensive Koletsky rat (SHROB). J Pharmacol Exp Ther, 1999, 288, 139-147.

9. Ernsberger P, Westbrooks KL, Christen MO, Schäfer SG: A second generation of centrally acting antihypertensive agents act on putative $\mathrm{I}_{1}$-imidazoline receptors. J Cardiovasc Pharmacol, 1992, 20, S1-S10.

10. Friedman JE, Ishizuka T, Liu S, Farrell CJ, Koletsky RJ, Bedol D, Ernsberger P: Anti-hyperglycemic activity of moxonidine: metabolic and molecular effects in obese spontaneously hypertensive rats. Blood Press Suppl, 1998, 3, 32-39.

11. George OK, Gonzalez RR Jr, Edwards LP: Moxonidine, an antihypertensive agent, is permissive to $\alpha_{1}$-adrenergic receptor pathway in the rat-tail artery. J Cardiovasc Pharmacol, 2004, 43, 306-311.

12. Haenni A, Lithell H: Moxonidine improves insulin sensitivity in insulin-resistant hypertensives. J Hypertens Suppl, 1999, 17, S29-S35.

13. Hansson L: Therapy of hypertension and metabolic syndrome: today's standard and tomorrow's perspectives. Blood Press, 1998, 3, 20-22.

14. Hofmann U, Burkard N, Vogt C, Thoma A, Frantz S, Ertl G, Ritter O, Bonz A: Protective effects of sphingosine1-phosphate receptor agonist treatment after myocardial ischaemia-reperfusion. Cardiovasc Res, 2009, 83, 285-293.

15. Horiuchi M, Akishita M, Dzau VJ: Molecular and cellular mechanism of angiotensin II-mediated apoptosis. Endocr Res, 1998, 24, 307-314.
16. Ivanov TR, Jones JC, Dontenwill M, Bousquet $\mathrm{P}$, Piletz JE: Characterization of a partial cDNA clone detected by imidazoline receptor-selective antisera. J Auton Nerv Syst, 1998, 72, 98-110.

17. Kennedy WB, Crane L, Gonzalez RR, George OK, Edwards LP: Centrally acting imidazolines stimulate vascular alpha $1 \mathrm{~A}$-adrenergic receptors in rat-tail artery. Cell Mol Neurobiol, 2006, 26, 645-657.

18. Li F,Wu N, Su RB, Zheng JQ, Xu B, Lu XO, Cong B, Li J: Involvement of phosphatidylcholine-selective phospholipase $\mathrm{C}$ in activation of mitogen-activated protein kinase pathways in imidazoline receptor antiseraselected protein. J Cell Biochem, 2006, 98, 1615-1628.

19. Misbin RI: The phantom of lactic acidosis due to metformin in patients with diabetes. Diabetes Care, 2004, 27, 1791-1793.

20. Molderings GJ, Bönisch H, Brüss M, Wolf C, von Kügelgen I, Göthert M: S1P-receptors in PC12 and transfected HEK293 cells: Molecular targets of hypotensive imidazoline $\mathrm{I}_{1}$ receptor ligands. Neurochem Int, 2007, 51, 476-485.

21. Molderings GJ, Bonisch H, Hammermann R, Gothert M, Bruss M: Noradrenaline release-inhibiting receptors on PC12 cells devoid of $\alpha_{2}$ - and $\mathrm{CB}_{1}$ receptors: similarities to presynaptic imidazoline and edge receptors. Neurochem Int, 2002, 40, 157-167.

22. Piletz JE, Ivanov TR, Sharp JD, Ernsberger P, Chang $\mathrm{CH}$, Pickard RT, Gold G et al.: Imidazoline receptor antisera-selected (IRAS) cDNA: cloning and characterization. DNA Cell Biol, 2000, 19, 319-329.

23. Piletz JE, Jones JC, Zhu H, Bishara O, Ernsberger P: Imidazoline receptor antisera-selected cDNA clone and mRNA distribution. Ann NY Acad Sci, 1999, 881, 1-7.

24. Sano H, Liu SC, Lane WS, Piletz JE, Lienhard GE: Insulin receptor substrate 4 associates with the protein IRAS. J Biol Chem, 2002, 277, 19439-19447.

25. Sun Z, Chang CH, Ernsberger P: Identification of IRAS/nischarin as an $\mathrm{I}_{1}$-imidazoline receptor in $\mathrm{PC} 12$ rat pheochromocytoma cells. J Neurochem, 2007, 101, 99-108.

26. Sun Z, Ernsberger P: Marked insulin resistance in obese spontaneously hypertensive rat adipocytes is ameliorated by in vivo but not in vitro treatment with moxonidine. J Pharmacol Exp Ther, 2007 320, 845-852.

27. Zhang J, Abdel-Rahman AA: Nischarin as a functional imidazoline $\left(\mathrm{I}_{1}\right)$ receptor. FEBS Lett, 2006, 580, 3070-3074.

Received: January 17, 2011; in the revised form: July 7, 2011; accepted: July 28, 2011. 